\title{
Anti-SRP-pozitív myositises betegeink klinikai sajátosságai és terápiára adott válaszuk
}

\author{
Botos Balázs dr. ${ }^{1}$ - Nagy-Vincze Melinda dr. ${ }^{2}$ - Dankó Katalin dr. ${ }^{2}$ \\ ${ }^{1}$ Borsod-Abaúj-Zemplén Megyei Központi Kórház és Egyetemi Oktatókórház, I. Belgyógyászati Osztály, Miskolc \\ ${ }^{2}$ Debreceni Egyetem Klinikai Központ, Belgyógyászati Intézet, Klinikai Immunológia Tanszék, Debrecen
}

\begin{abstract}
Bevezetés: Az idiopathiás inflammatorikus myopathiák klinikai képe heterogén, csoportosításuk újabban a myositisspecifikus antitestek alapján történik. Egyik jellegzetes képviselőjük a szignálfelismerő részecske elleni antitest (antiSRP-) pozitív típus, amelynek klinikai megjelenését súlyosabbnak tartják a többi myositisspecifikus antitestpozitív formához képest.

Célkitüzés: A Debreceni Egyetem Belgyógyászati Intézetének Klinikai Immunológia Tanszékén kezelt 16 anti-SRPpozitív csoportba tartozó beteg klinikai és kezelési adatainak összehasonlítása volt 16 antitestnegatív esettel.

Módszer: Az anti-SRP-pozitív csoportban a manual muscle teszttel vizsgált izomgyengeség a kezelés előtt és után szignifikáns különbséget mutatott a kontrollcsoporthoz képest $\left(\chi^{2}=0,006\right.$, illetve 0,019$)$. A különbség a vázizmokra specifikus gyulladásos laboratóriumi paramétereknél ugyanígy jelentkezett, de a kezelés utáni laktátdehidrogenázértékek kivételével nem volt szignifikáns.

Eredmények: Első vonalbeli szteroidkezelésre mindkét csoport jól reagált, azonban az antitestpozitív csoport rosszabb terápiás válaszát jelzi, hogy szignifikánsan több esetben volt szükség másodvonalbeli kezelésre.

Következtetés: Mindezek alapján az anti-SRP-pozitív csoport súlyosabb klinikai lefutását és rosszabb terápiás válaszát állapítottuk meg.

Orv Hetil. 2017; 158(35): 1382-1389.
\end{abstract}

Kulcsszavak: szignálfelismerő részecske, idiopathiás inflammatorikus myopathia, manual muscle test

\section{Clinical features and therapeutic response of our anti-SRP positive patients with myositis}

Introduction: Idiopathic inflammatory myopathies are a group of clinically heterogeneous diseases, which have been classified by myositis specific antibodies recently. The anti-SRP positive subset of this group is characterized by more severe clinical prognosis than other myositis specific antibody positive types.

Aim: Our goal was to compare 16 anti-SRP positive patients in the Division of Clinical Immunology, Department of Internal Medicine, University of Debrecen with 16 antibody negative ones.

Method: Muscle strength validated in both groups by the manual muscle test proved to be significantly decreased both before and after therapy $\left(\chi^{2}=0.006\right.$ and 0.019$)$ in the anti-SRP positive group.

Results: Muscle-specific inflammatory laboratory parameters showed significant difference only in case of LDH-levels after therapy. Both groups showed good clinical response to first line steroid treatment, yet the significantly higher rate of second line administration suggests worse therapeutic response of the antibody positive group.

Conclusion: Based on these facts we determined poor clinical prognosis and therapeutic response of the anti-SRP positive group.

Keywords: SRP (signal recognition particle), idiopathic inflammatory myopathy, manual muscle test

Botos B, Nagy-Vincze M, Dankó K. [Clinical features and therapeutic response of our anti-SRP positive patients with myositis]. Orv Hetil. 2017; 158(35): 1382-1389.

(Beérkezett: 2017. június 17.; elfogadva: 2017. július 10.) 


\section{Rövidítések}

aJo-1 = Jo-1 elleni antitest; $\mathrm{aMi}-2=\mathrm{Mi}-2$ elleni antitest; aSRP $=$ (antibody to signal recognition particle) szignálfelismerô részecske elleni antitest; DM = dermatomyositis; IIM = idiopathiás inflammatorikus myopathia; ILD = (interstitial lung disease) interstitialis tüdőbetegség; $\mathrm{MAA}=$ myositisasszociált antitest; $\mathrm{MMT}=$ (manual muscle test) kéziizomerő-vizsgálat; MSA = myositisspecifikus antitest; NAM = nekrotizáló autoimmun myopathia; $\mathrm{PM}=$ polymyositis $\mathrm{RF}=$ reumafaktor; $\mathrm{SRP}=$ (signal recognition particle) szignálfelismerô részecske

Az idiopathiás inflammatorikus myopathiák (IIM) szisztémás autoimmun kórképek. Közös jellegzetességük az immunmediált krónikus gyulladás, amely a proximális végtagizmokat szimmetrikusan érinti és progresszív izomgyengeséghez vezet.

A multifaktoriális etiológiájú betegségcsoport előfordulása ritka, incidenciájuk 1,16-19/millió/év, prevalenciájuk 2,4-33,8/100 000, és a nők körében háromszor gyakrabban jelentkeznek [1].

A klinikai képet elsősorban az alsó és/vagy felső végtagok proximális részére lokalizált izomgyengeség és esetleges izomfájdalom jellemzi, distalis érintettség általában csak ritkán, a kórlefolyás során később jelentkezik. Érintettek lehetnek a nyak hajlítóizmai is, a mimikai izmok, viszont az ocularis izomzat rendszerint megkímélt.

Bőrtünetek előfordulása elsősorban a kórképek egyik alcsoportjában, a dermatomyositisben jellemző. A betegségre patognomikus bőrtünet a metacarpophalangealis és interphalangealis ízületek felett megjelenő erythema, az úgynevezett Gottron-papula, valamint a Gottron-jel, amely a térd, könyök és boka belső felszíne felett szimmetrikusan megjelenő vörhenyes papula.

A karakterisztikus tünetek közé tartozik a heliotrop rash, ami alatt a szemhéjak lilás elszíneződését értjük. A V jel a ruha kivágásának megfelelően megjelenő erythema. Idetartozik még a facialis erythema, valamint a periungualis teleangiectasia is.

Ritkább előfordulású a calcinosis, mechanikus kéz, szimmetrikus macularis erythema, teleangiectasiák, poikiloderma, hypo- és hyperpigmentatio, subepidermalis bullák, felszínes eróziók, panniculitis, urticaria, ichtyosis, hajhullás, viszketés.

Extraskeletalis manifesztációk megjelenhetnek a gastrointestinalis traktusban a nyelőcső érintettsége képében, involvált lehet az oropharynx, a gége- és légzőizmok, valamint a szívizom is. A betegek ugyanakkor bizonyos overlap tüneteket is mutathatnak, mint a tüdőben megjelenő interstitialis tüdőbetegség (ILD) és más szisztémás érintettség, valamint arthritis [2-4].

A gyulladásos izombetegségek diagnosztikus kritériumrendszerét Boban és Peter fogalmazta meg 1975-ben, ami az alábbiakat foglalja magában:

- szimmetrikus izomgyengeség a proximális végtagizmokban;

- emelkedett, harántcsíkolt izomzatra jellegzetes enzimszintek (kreatinkináz [CK], laktátdehidrogenáz
[LDH], glutamát-oxálacetát-transzamináz [GOT], glutamát-piruvát-transzamináz [GPT]);

- a betegségre karakterisztikus EMG-triász (kis ingadozású, polifázisos hullámok, magas frekvenciájú tüskék, spontán fibrilláció és pozitív meredek hullámok);

- pozitív izombiopszia, amely mononukleáris sejtes beszürődést, nekrózist, phagocytosist, az izomrostok elfajulását és regenerációját, kapilláriselzáródást, kötőszöveti felszaporodást mutathat;

- dermatomyositis esetén jellegzetes bőrtünetek.

A betegséget Bohan és Peter hat, klinikopatológiai szempontból elkülöníthető csoportba sorolta be. E szerint megkülönböztetünk felnőttkori polymyositist (PM), felnőttkori dermatomyositist (DM), tumorral társult myositist, gyermekkori PM/DM-et, egyéb autoimmun betegséggel társult PM/DM-et, valamint szintén az IIM-csoportba sorolt zárványtestes myositist $[2,3]$.

A felnőttkorban két leggyakrabban előforduló típus a polymyositis és dermatomyositis. Patológiailag a polymyositis elsősorban CD8+ T-sejt-vezérelt krónikus gyulladásos folyamat, amely során endomysialis infiltráció történik, és az aktivált T-sejtek proinflammatorikus citokinkaszkádot indítanak, valamint makrofágokat aktiválnak. Dermatomyositisben ezzel szemben perivascularis infiltráció dominál, amely során CD4+ T-sejtek indítanak be citokinútvonalakat, valamint itt a B-sejtek által kiváltott humorális mechanizmusok is nagyobb szereppel bírnak [5].

A zárványtestes myositis patofiziológiai szempontból kiemelendő az alcsoportok közül, nevét az izomsejtekben megfigyelhető zárványtestekről kapta. Klinikailag gyakrabban mutat distalis érintettséget, és nemegyszer aszimmetrikusan jelentkezik a végtagok izomgyengesége.

A gyulladásos izombetegségek tumorral és más autoimmun betegségekkel is társulhatnak, ezt a BohanPeter-féle beosztás külön alcsoportba sorolja.

Tumorhoz társult myositist állapítunk meg, ha a daganat a betegség megjelenését megelőző vagy azt követő két évben jelentkezik. Felnőttkorban gyakoribb előfordulást mutatnak az ovarium-, emlő-, tüdő- és gyomordaganatok, gyermekeknél pedig a hematológiai malignus betegségek dominálnak.

Overlap myositis esetén a gyulladásos izombetegségek más szisztémás autoimmun betegséggel társulhatnak, leggyakrabban SLE-vel, rheumatoid arthritisszel, sclerodermával, szisztémás sclerosissal, kevert kötőszöveti betegséggel. Az overlapesetek polymyositisben gyakoribb előfordulást mutatnak.

A juvenilis PM/DM, amely 18 év alatt manifesztálódik, szintén külön alcsoportként klasszifikált. Ez a forma leggyakrabban dermatomyositishez asszociált, és kedvező prognózist mutat [3-5].

A klasszikus Bohan-Peter-féle osztályozás, bár klinikopatológiai szempontból jól elkülöníthető alcsoportokat hozott létre, ezek az alcsoportok prognosztikai és terápiás szempontból meglehetősen heterogének marad- 
tak. A betegségcsoportban előforduló antitesteket vizsgálva azonban új lehetőség nyílt a gyulladásos izombetegségek klinikai gyakorlati szempontból történő osztályozására. Ezeknek az antitesteknek két típusa létezik: az úgynevezett myositisspecifikus és myositisasszociált antitestek. A myositisspecifikus antitestek (MSA) jellemzője, hogy kizárólag az idiopathiás inflammatorikus myopathiákban fordulnak elö, míg a myositisasszociált antitestek (MAA) rendszerint azokban a betegekben azonosíthatók, akik overlapmyositisben szenvednek, azaz egyéb szisztémás autoimmun betegségük is jelen van. A specifikus antitestek előfordulási aránya közel 30\% a gyulladásos izombetegségekben. Az esetek többségében a betegek csak egyféle MSA-val rendelkeznek, amely már a betegség kezdete előtt megjelenhet és szérumszintje korrelál a betegség aktivitásával is.

Az elmúlt évek myositisspecikus antitestekkel foglalkozó tanulmányai végül rámutattak arra, hogy a szerológiai alapon besorolt betegségcsoportok klinikai tüneteikben és lefolyásukban egymástól eltérnek, ami egyben az osztályozás új alapját jelentette [6-8].

Jelenleg három fó szerológiai alcsoportot különböztetnek meg: az anti-Jo-1, az anti-Mi-2 és az anti-SRP antitestpozitív csoportokat. Az említett antitesteken túl léteznek viszont újabb, a közelmúltban azonosított MSA-k is, mint az anti-TIF1, anti-NXP2, anti-SAE, anti-MDA5, anti-HMGCR és anti-cNlA [9].

A legjobb prognózisú szerológiai alcsoport az antiMi-2-pozitív típus. Rendszerint dermatomyositisben vagy juvenilis dermatomyositisben jelentkezik, és a betegségre jellegzetes bőrtünetek kísérik, leggyakrabban Gottron-papula, heliotrop rash, V jel és sáljel. Az alcsoport patogenezisében újabban a környezeti tényezók szerepét találták kiemelkedőnek, miután összefüggést találtak az UV-sugárzás és az anti-Mi-2 antitestek jelenléte között [10]. Az Mi-2 protein emellett a bőrepidermis bazális részének javításában esszenciálisnak bizonyult, ami összefügghet az alcsoportra jellemző bőrtünetek gyakori megjelenésével [11].

Az anti-Jo-1 típusnál ritkábbak a bőrtünetek, viszont gyakoribb a szervi érintettség, amely fooleg a tüdőben ILD formájában fordul elő, és arthritis, Raynaud-jelenség, mechanikus kéz, valamint láz is kísérheti. Ezt a tünetegyüttest antiszintetáz szindrómának nevezzük.

Az anti-Jo-1-antitestpozitív betegek jól reagálhatnak a kezdeti szteroidterápiára, azonban a későbbi relapsus aránya magasabb, mint a negatívak esetén. Az antitest titere viszonylag jól korrelál a CK-értékekkel és a betegség aktivitásával [12].

$\mathrm{Az}$ anti-SRP-pozitív szerológiai csoport tekinthető a legrosszabb prognózisúnak, itt ugyanis súlyosabb izomgyengeség, rossz terápiás válasz, valamint remissziókkal-relapsusokkal tarkított gyors progresszió figyelhető meg. A szervi manifesztációk közül a szívérintettség említhető meg elsősorban, amelyet korábbi tanulmányok gyakran hangsúlyoztak $[13,14]$, újabban azonban ennek megjelenését kétségbe vonják [15-17]. Ehhez ha- sonlóan egyes újabb kutatások szteroidra adott jó választ is megfigyeltek, és ugyancsak kedvező eredményt láttak immunterápia alkalmazása során. Megjegyzik azonban, hogy mindezek ellenére a relapsus aránya magas [15, 16].

A myositisasszociált antitestek (MAA) képviselői az anti-PM-Scl, anti-U1-, U2-, U3-RNP, anti-Ku, antiSSA, anti-SSB és RF (reumafaktor) antitestek. Az anti$\mathrm{Ku}$ antitest legtöbbször szisztémás sclerosishoz és SLEhez, az anti-SSA és anti-SSB Sjögren-szindrómához, az RF rheumatoid arthritishez, az anti-UlRNP pedig kevert kötőszöveti betegséghez társul [18].

Az SRP-proteinnek fiziológiásan a sejt által újonnan szintetizált fehérjék felismerésében és endoplazmatikus reticulumon keresztüli transzlokációjában van szerepe.

A szignálfelismerő részecske ellen irányuló antitestek a felnőtt myositises lakosság mintegy 5\%-ában fordulnak elő [14]. Az antitestek jelenlétét már a '80-as évek végén leírták, pár év elteltével pedig felismerték, hogy a betegség ugyan a klasszikus polymyositishez hasonlít, néhány esetben viszont szokatlanul súlyos megjelenés és gyors lefolyás várható [19]. 2004-ben a Muscle Study Group az aSRP-alcsoportot a nekrotizáló autoimmun myopathiák (NAM) képviselőjeként azonosította, amelynek patológiai jellemzője, hogy az izomrostnekrózisért a T-sejtek helyett a makrofágok felelnek, míg az előbbi sejttípus gyakran hiányzik [20]. A nekrotizáló autoimmun myopathiákat három fó faktor indukálhatja: statinterápia, tumoros érintettség vagy infekció. A folyamat kialakulásáért a szérumból kimutatható autoantitestek felelnek, ezért a reakció egy autoantitest-mediált sejtdependens citotoxicitásnak tekinthető, amely folyamatban komplementdepozitumok szerepét is igazolták. Szövettanilag nekrózis, felszaporodott endomysialis kötőszövet és az endomysialis kapillárisok csökkent száma figyelhető meg [16].

Az anti-SRP mellett az utóbbi időben egy újabb antitestet, az anti-pl00/200-at is sikerült azonosítani, amely szintén a NAM kialakulásához vezethet [21].

Az eddig összegyúlt irodalmi adatok alapján az SRP ellen irányuló antitestpozitív betegségre az alábbiak jellemzőek: akut, súlyos kezdet, erősen emelkedett enzimszintek, valamint előfordulhat szívérintettség. A betegek refrakterek lehetnek a standard terápiákra, gyakoribb a relapsus és rosszabb a prognózis [13-17, 21-23].

\section{Módszer}

Vizsgálatunk során a DEKK Belgyógyászati Intézet Klinikai Immunológia Tanszékén kezelt 16 aSRP-pozitív myositises beteg adatait és 16 MSA-negatív kontrollbeteg adatait retrospektíve elemeztük.

A demográfiai homogenitást t-próbával ellenőriztük, míg a klinikum és a terápiás válaszkészség különbségeit a Mann-Whitney- és $\chi^{2}$-próbákkal vizsgáltuk. A statisztikai elemzéshez az SPSS17 szoftvert használtuk. 
Az antitestek meghatározása az ORGENTEC Diagnostika GmbH ORG 760 Myositis plus kitjével történt, immunoblottechnikával. (Vizsgált antitestek: anti-SSA, anti-SSB, anti-PM/Scl, anti-Scl70, anti-Ku, anti-UlRNP, anti-dsDNA, RF, anti-SRP, anti-Mi-2, anti-Jo-1.)

A betegek izomerejét a Rider és mtsai által validált manual muscle test (MMT) segítségével állapítottuk meg [24]. Minden páciensnél standardizált fizikális vizsgálómódszerrel értékeltük nyolc izomcsoport funkcióját, és azt 0-tól 10-es skálán pontoztuk.

A laboratóriumi paraméterek közül a CK- és $\mathrm{LDH}-$ értékeket kiemelten vizsgáltuk, mivel a betegségre jellemző izomsejt-károsodás során ezen enzimek szérumszintje jellemzően jelentősen megemelkedhet.

Vizsgáltuk a betegségcsoportra jellemző bőrtünetek jelenlétét (V jel, heliotrop rash, Gottron-papula, Gottron-jel, sáljel, periungualis oedema, mechanikus kéz), valamint a szisztémás érintettséget (dysphagia, tüdőérintettség, szívérintettség, arthritis, láz). Tüdőérintettséget nagy felbontású mellkasi CT-vel igazolható alveolitis vagy fibrosis, szívérintettséget a betegséggel egyidejüleg fennálló myocarditis, pericarditis, dilatatív cardiomyopathia vagy arrhythmia esetén állapítottunk meg.

A betegek első vonalban választandó kezelését a szteroidterápia képezte, amit Dankó szerint [25] háromnégy hétig nagy dózisban alkalmaztunk $(0,5-3 \mathrm{mg} /$ ttkg/nap), majd megfelelő terápiás válasz esetén 10 héten át mérsékeltünk másnaponta $0,5 \mathrm{mg}$-mal. Súlyos esetben a szteroidterápiát bolusban indítottuk, három napig $1 \mathrm{~g} /$ nap dózisban. Jó szteroidreakciónak tekintettük, ha másodvonalbeli szer nélkül remissziót lehetett elérni, az enzimértékek és az MMT értékei is visszatértek a referenciatartományba.

Másodvonalbeli terápiát indítottunk, ha a szteroidkezelés két hónap után sem volt sikeres vagy a tartós kezelés miatt szteroidspóroló terápia bevezetése vált szükségessé. Ilyenkor a kedvező mellékhatásprofillal rendelkező azathioprint választottuk. Súlyos, gyorsan progrediáló esetekben eleve másodvonalbeli szert is adtunk a szteroid mellé. Ezt indokolta, ha a beteg állapota gyorsan romlott, súlyos dysphagia vagy légzőizom-elégtelenség, szervi érintettség fordult elö.

Másodvonalbeli szerként az azathioprint 2-3 mg/kg/ nap dózisban alkalmaztuk. A cyclophosphamidot $0,7 \mathrm{~g}$ vagy $1 \mathrm{~g} / \mathrm{m}^{2}$ adagban, a methotrexatot 7,5 mg/hét kezdődózissal három héten át, majd hetente 2,5 mg-mal emelve $25 \mathrm{mg}$ /hét dózisig adtuk.

Ezek mellett a szokásos dozírozási előírás szerint cyclosporin A-t, három súlyos esetben IVIG-et, illetve egy betegnél rituximabkezelést is alkalmaztunk az aSRP-pozitív csoportban.

$\mathrm{Az}$ idiopathiás inflammatorikus myopathiákat lefolyásuk szerint monofázisos, polifázisos és krónikus formába soroltuk. Monofázisos kórlefolyásról beszéltünk, ha a kezdeti terápia után tartós remisszióba került a beteg és nem fordult elö relapsus.
1. táblázat $\mid$ Az aSRP-pozitív és aSRP-negatív csoport demográfiai adatainak összehasonlítása

\begin{tabular}{lccc}
\hline & aSRP+ & aSRP- (kontroll) & t-próba $(\mathrm{p}=)$ \\
\hline Kor & 59,25 & $60,06(13,772)$ & 0,876 \\
& $(15,299)$ & & \\
Kor a betegség & 48,94 & $48,94(13,473)$ & 0,940 \\
jelentkezésekor & $(17,338)$ & & \\
\hline
\end{tabular}

\section{aSRP+ $\quad$ aSRP- (kontroll) $\quad \chi^{2}$-próba $(\mathrm{p}=)$}

\begin{tabular}{crrr}
\hline Nem & & & \\
Férfi & 2 & 2 & 1,000 \\
Nó & 14 & 14 & 1,000 \\
\hline
\end{tabular}

aSRP+ $\quad$ aSRP- $($ kontroll $) \quad \chi^{2}$-próba $(\mathrm{p}=)$

Klinikopatológiai

csoportok

$\begin{array}{lrrr}\text { Polymyositis } & 12 & 13 & 0,669 \\ \text { Dermatomyositis } & 3 & 3 & 1,000 \\ \text { Zárványtestes } & 1 & 0 & 0,310 \\ \text { myositis } & & & \end{array}$

myositis

Relapsust követő későbbi remissziós-relapsusos epizódok esetén polifázisos lefolyást állapítottunk meg.

Krónikusnak tekintettük a betegséget, ha nem tudtunk teljes remissziót elérni, és a betegség aktivitása hullámzó lefolyást mutatott.

\section{Eredmények}

Az aSRP-pozitív és negatív csoport átlagéletkor, a betegség megjelenésekori életkor, valamint a férfi-nő arány tekintetében nem mutatott szignifikáns különbséget $(\mathrm{p}=0,876, \mathrm{p}=0,940$ és $\mathrm{p}=1,000)$, így a vizsgált csoportokat statisztikailag homogénnek lehet tekinteni.

A két csoport a klinikopatológiai kategóriákban sem tért el egymástól, de megjegyzendő, hogy míg az irodalom az aSRP-pozitív szerológiai csoport polymyositishez való társulását hangsúlyozza $[14,15]$, addig mi három dermatomyositises és egy zárványtestes myositises társulást is találtunk a betegek között (1. táblázat).

Az idiopathiás inflammatorikus myopathiákban megjelenő antitestek közül myositisasszociált antitestet három anti-SRP-pozitív betegnél találtunk (egy anti-Ku- és két RF-pozitivitás), míg a kontrollcsoportban MAA-t nem észleltünk. Az első csoport anti-Ku-pozitív betegénél más szisztémás autoimmun betegség nem volt jelen, míg az RF antitestpozitív betegek rheumatoid arthritisben is szenvedtek.

A 16 aSRP-pozitív beteg közül két esetben kettős MSA-társulás volt jelen, egy esetben aMi-2, a másik esetben aJo-1 volt igazolható.

Az aSRP-pozitív csoportban az izomgyengeség kezdetben, valamint a kezelés után is súlyosabb volt a kont- 
MMT (manual muscle test)

pontszám

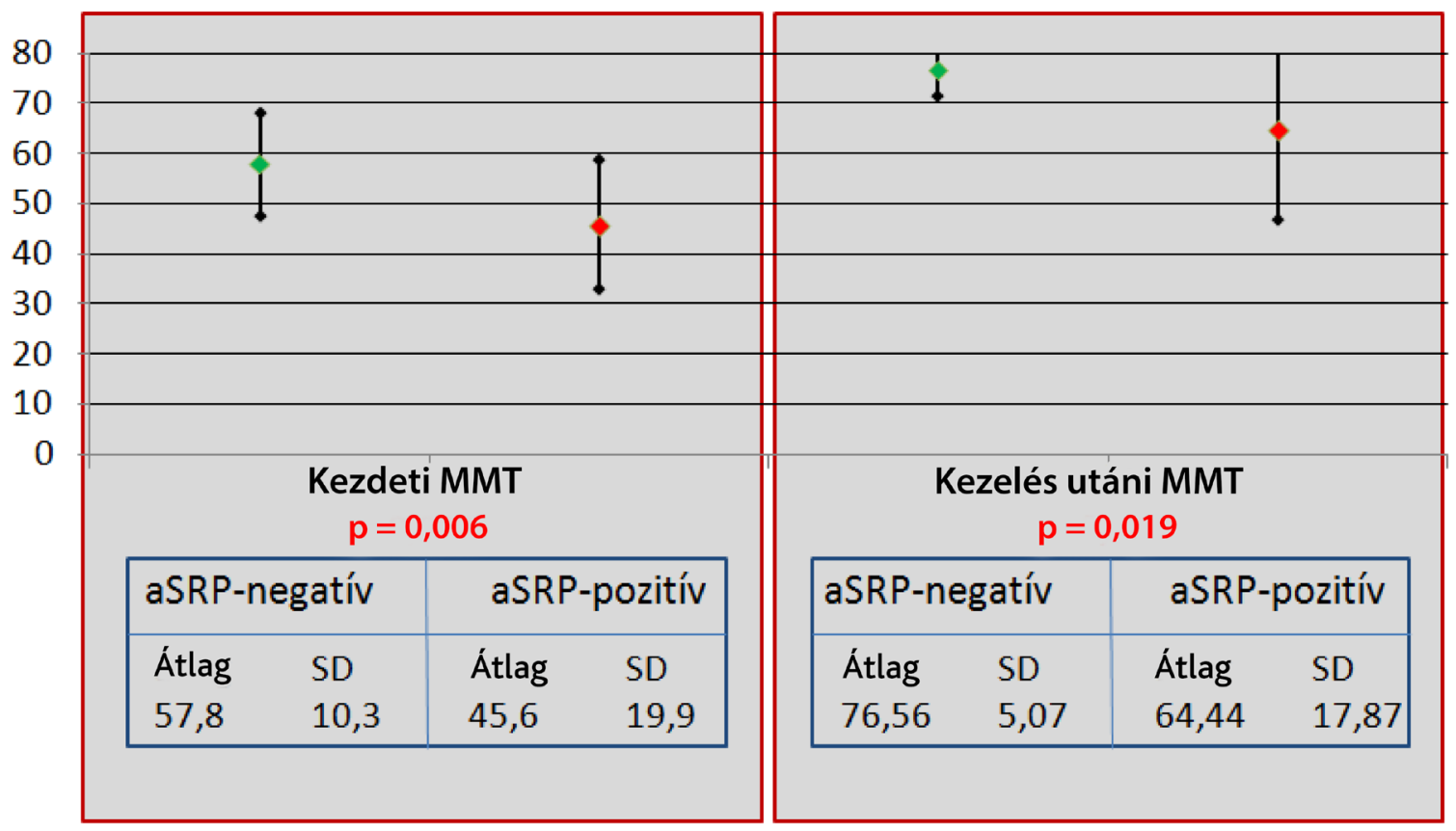

1. ábra $\quad$ Az aSRP-pozitív és aSRP-negatív csoport kezdeti és kezelés után mért izomerejének összehasonlítása

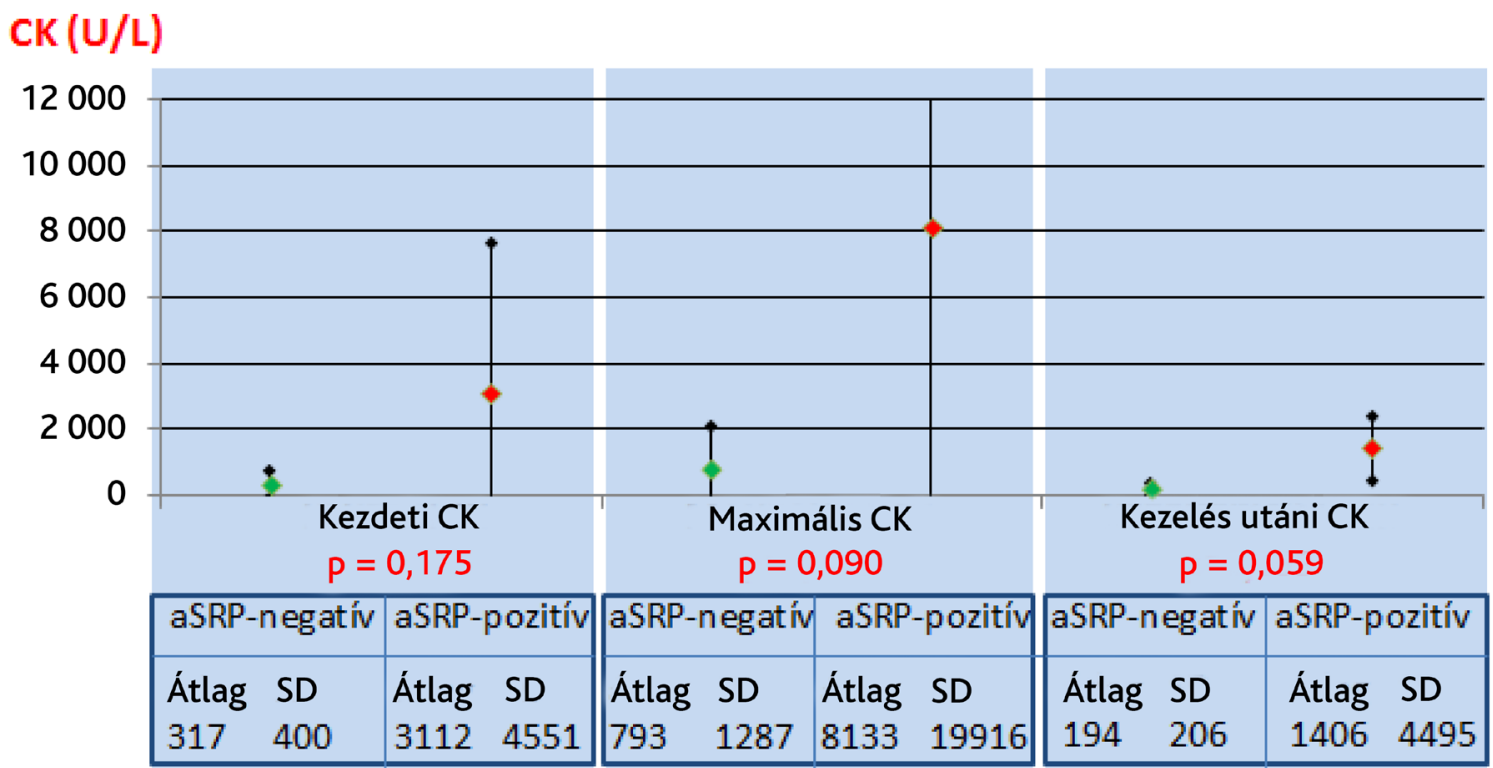

2. ábra |Az aSRP-pozitív és aSRP-negatív csoport kezdeti, maximális és kezelés után mért CK-szintjeinek összehasonlítása

rollcsoporthoz képest, az MMT-értékek között mindkét esetben szignifikáns különbséget találtunk (1. ábra).

A kreatinkináz és a laktátdehidrogenáz enzimek kezdeti, maximális és a kezelést követô szintjét határoztuk meg.

Az aSRP+ csoportban a CK átlagértéke mindhárom vizsgált idópontban magasabb volt az aSRP-negatív csoporthoz képest, de statisztikai próbával nem találtunk szignifikáns különbséget (2.ábra).
Az LDH-értékek vizsgálata során is mindhárom vizsgált időpontban magasabb középértékeket találtunk, de itt a kezelés utáni LDH-értékek szignifikáns különbséget is mutattak (3. ábra).

A klinikai manifesztációk és tünetek tekintetében nem találtunk szignifikáns különbséget a két csoport között (2. táblázat).

A vizsgálatunkban szereplő 16 aSRP-pozitív betegből kilenc reagált jól a kezdeti szteroidterápiára, míg a kont- 


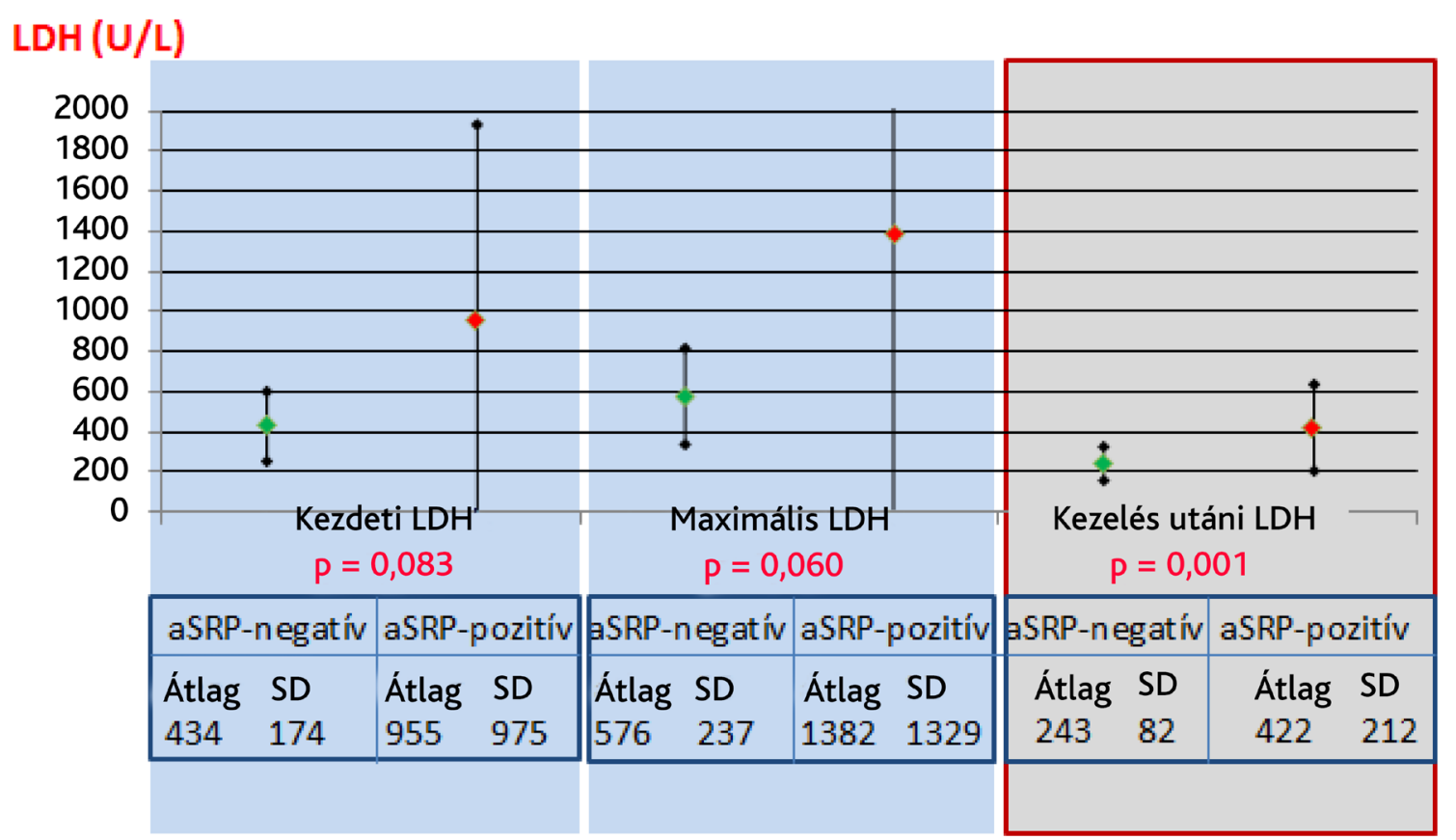

rollcsoportban 11 betegnél értünk el remissziót, így a szteroidkezelésre adott terápiás válasz tekintetében szignifikáns különbséget nem észleltünk ( $\mathrm{p}=0,465)$.

Másodvonalbeli kezelés indítására az anti-SRP-pozitív-csoportban 13 esetben volt szükség, a kontrollcsoportban ezzel szemben hét esetben, amely különbség szignifikáns eltérést mutatott $(\mathrm{p}=0,028)$ (4. ábra).

Az anti-SRP-pozitív csoport kezdeti kilenc, szteroidra jól reagáló betege közül öt beteg kórlefolyása relapsust mutatott, így négy esetben láttunk monofázisos, öt esetben pedig polifázisos lefolyást. Hét betegnél sosem sikerült remissziót elérni, náluk krónikus lefolyást figyeltünk meg.

2. táblázat $\mid$ Az aSRP-pozitív és aSRP-negatív csoport klinikai tüneteinek összehasonlítása

\begin{tabular}{lccc}
\hline & aSRP+ & $\begin{array}{c}\text { aSRP- } \\
\text { (kontroll) }\end{array}$ & $\begin{array}{c}\chi^{2} \text {-próba } \\
(\mathrm{p}=)\end{array}$ \\
\hline Szívérintettség & 2 & 1 & 0,544 \\
Tüdőérintettség & 3 & 4 & 0,669 \\
Dysphagia & 6 & 4 & 0,446 \\
Raynaud-jelenség & 10 & 6 & 0,157 \\
Arthritis & 11 & 12 & 0,694 \\
V jel & 3 & 3 & 1,000 \\
Heliotrop rash & 4 & 3 & 0,669 \\
Gottron-jel & 5 & 3 & 0,414 \\
Sáljel & 2 & 3 & 0,626 \\
Periungualis oedema & 1 & 2 & 0,544 \\
Mechanikus kéz & 2 & 3 & 0,626 \\
Láz & 3 & 1 & 0,285 \\
\hline
\end{tabular}

A kontrollcsoportban 11 betegnél mutatkozott remisszió, ebből mindössze kettőnél fordult elő relapsus, így kilenc beteg esetében monofázisos, kettőnél pedig polifázisos lefolyást állapítottunk meg. Öt beteg esetében nem sikerült remissziót elérni.

A két csoport között a remisszió, relapsus, monofázisos, polifázisos és krónikus lefolyás tekintetében nem találtunk szignifikáns különbséget $(\mathrm{p}=0,465, \mathrm{p}=0,200$, $\mathrm{p}=0,072, \mathrm{p}=0,200$ és $\mathrm{p}=0,465)$ (3. táblázat).

\section{Megbeszélés}

Az idiopathiás inflammatorikus myopathiák izomgyengeséggel és izomfájdalommal járó megbetegedések, amelyek színes klinikai palettája és változatos kórlefolyása már régóta arra adott okot, hogy a betegséget új alapon osztályozzák. A myositisspecifikus antitestek az eddig tapasztaltak alapján úgy tünik, hogy beváltják az ehhez füzött reményeket, hiszen a specifikus antitest-pozitivitás alapján történő osztályozás a klinikai tünetek és

3. táblázat $\mid$ Az aSRP-pozitív és aSRP-negatív csoport klinikai lefolyásának összehasonlítása

\begin{tabular}{lccc}
\hline & aSRP+ & $\begin{array}{c}\text { aSRP- } \\
\text { (kontroll) }\end{array}$ & $\begin{array}{c}\chi^{2} \text {-próba } \\
(\mathrm{p}=)\end{array}$ \\
\hline Remisszió & 9 & 11 & 0,465 \\
Relapsus & 5 & 2 & 0,200 \\
Monofázisos lefolyás & 4 & 9 & 0,072 \\
Polifázisos lefolyás & 5 & 2 & 0,200 \\
Krónikus lefolyás & 7 & 5 & 0,465 \\
\hline
\end{tabular}




\begin{tabular}{|l|l|l|l|l|c|}
\hline & \multicolumn{2}{|c|}{ aSRP+ } & \multicolumn{2}{c|}{ aSRP- } & $\chi^{2}$ \\
\hline $\begin{array}{l}\text { Első } \\
\text { vonalbeli } \\
\text { szer }\end{array}$ & Jól reagált & $\begin{array}{l}\text { Nem reagált } \\
\text { jól }\end{array}$ & Jól reagált & $\begin{array}{l}\text { Nem reagált } \\
\text { jól }\end{array}$ & \\
\cline { 2 - 6 } & 9 & 7 & 11 & 5 & 0,465 \\
\hline
\end{tabular}

\begin{tabular}{|c|c|c|c|c|c|c|c|c|}
\hline \multirow{2}{*}{$\begin{array}{l}\text { Másod- } \\
\text { vonalbeli } \\
\text { szer }\end{array}$} & \multicolumn{3}{|c|}{ aSRP+ } & & \multicolumn{3}{|c|}{ aSRP- } & \multirow[t]{2}{*}{$x^{2}$} \\
\hline & \multicolumn{2}{|c|}{ Kapott } & \multicolumn{2}{|c|}{ Nem kapott } & Kapott & & \multirow[t]{2}{*}{ Nem kapott } & \\
\hline & \multicolumn{2}{|l|}{13} & \multicolumn{2}{|l|}{3} & 7 & \begin{tabular}{l|l}
9 & 9
\end{tabular} & & 0,028 \\
\hline \multicolumn{2}{|c|}{ Jól reagált } & \multicolumn{2}{|c|}{ Nem reagált jól } & \multicolumn{2}{|c|}{ Jól reagált } & \multicolumn{2}{|c|}{ Nem reagált jól } & \\
\hline \multicolumn{2}{|l|}{6} & \multicolumn{2}{|l|}{7} & \multicolumn{2}{|l|}{3} & \multicolumn{2}{|c|}{4} & \\
\hline
\end{tabular}

4. ábra | Az aSRP-pozitív és aSRP-negatív csoport terápiás válaszának összehasonlítása

terápiás válasz szempontjából egységesebb csoportokat hozott létre a betegségen belül.

A '80-as években felfedezett szignálfelismerô részecske egyike azon célmolekuláknak, amelyek ellen a myositisspecifikus antitestek irányulhatnak. Az ilyen antitestre (anti-SRP) pozitív betegek az összes myositises beteg mintegy 5\%-át képezik, és irodalmi adatok alapján roszszabb klinikai prognózis várható esetükben.

Tanulmányunk során megvizsgáltuk a gyulladásos izombetegségekre jellemző izomgyengeséget mind a vázizmokon, mind a sima- és szívizomzaton az aSRPpozitív és a kontrollcsoportban. Az irodalom által korábban hangsúlyozott szívizom-érintettséget nem találtuk gyakoribbnak az anti-SRP-pozitív alcsoportban.

$\mathrm{Az}$ antitestpozitív betegeknél a vázizomgyengeséget már a kezelés előtt súlyosabbnak találtuk a kontrollcsoporthoz képest, amit a nemzetközi tapasztalatok is megerősítenek [14-17, 22]. A kezelés megkezdése után az izomgyengeség továbbra is súlyosabb maradt az antitestpozitív betegek esetén, amit az alcsoport rosszabb terápiás válaszkészsége magyarázhat. Hasonlóan ezt a megállapítást támasztja alá a kezelés után mért LDH-értékeink eredménye, amely az anti-SRP-pozitív csoportban szignifikánsan magasabb maradt a terápia megkezdése után is.

A nemzetközi irodalom - eredményeinkhez hasonlóan - az aSRP-csoport rossz terápiás válaszát hangsúlyozza, azonban más vélemények is születtek ennek tekintetében. Miller és mtsai az időben megkezdett kortikoszteroidkezelés esetén az izomerő számottevő javulásáról számoltak be betegeiken [16]. Hengstman és $m$ tsai közleményükben szintén jó, kortikoszteroid és im- munszuppresszív szerekre adott válaszról írnak, megjegyzik azonban, hogy a relapsusráta így is magas [15].

\section{Következtetés}

Eredményeink azt mutatják, hogy az aSRP+ csoport a primer kezelésként adott szteroidterápiára jól reagált, viszont később többször volt szükség másodvonalbeli kezelésre, mint a kontrollcsoportban. A saját anyagunkban a relapsusrátát nem találtuk szignifikánsan magasabbnak az antitestnegatív csoporthoz képest, így adataink látszólag ellentmondanak az irodalomban tapasztaltaknak [15, 16]. Meg kell azonban jegyeznünk, hogy a vizsgált betegek száma viszonylag alacsony, ami a betegség prevalenciájának ismeretében nem meglepő. Az is látható az adatokból, hogy az aSRP+ csoport magasabb relapsusrátája megközelíti a szignifikancia határát, így lehetséges, hogy további betegek jelentkezése esetén már valódi szignifikáns eltérést mérhetnénk.

Anyagi támogatás: A közlemény megírása anyagi támogatásban nem részesült.

Szerzői munkamegosztás: B. B.: Anyaggyújtés, feldolgozás, statisztikai elemzések elkészítése, publikáció elkészítése. D. K., N.-V. M.: Releváns irodalmi adatok szintézise. Segítségnyújtás az anyagfeldolgozás, a statisztikai elemzések és a publikáció elkészítésében. A cikk végleges változatát valamennyi szerző elolvasta és jóváhagyta.

Érdekeltségek: A szerzőknek nincsenek érdekeltségeik. 


\section{Irodalom}

[1] Meyer A, Meyer N, Schaeffer M, et al. Incidence and prevalence of inflammatory myopathies: a systematic review. Rheumatology (Oxford) 2015; 54: 50-63.

[2] Bohan A, Peter JB. Polymyositis and dermatomyositis (first of two parts). N Engl J Med. 1975; 292: 344-347.

[3] Bohan A, Peter JB. Polymyositis and dermatomyositis (second of two parts). N Engl J Med. 1975; 292: 403-407.

[4] Dankó K, Czirják L. Inflammatory myopathies. In: Czirják L. (ed.) Clinical immunology. [Gyulladásos izombetegségek. In: Czirják L. (szerk.) Klinikai immunológia.] Medicina Könyvkiadó, Budapest, 2006; pp. 178-190. [Hungarian]

[5] Dalakas MC. Immunopathogenesis of inflammatory myopathies. Ann Neurol. 1995; 37(Suppl 1): S74-S86.

[6] Mimori T. Autoantibodies in connective tissue diseases: clinical significance and analysis of target autoantigens. Intern Med. 1999; 38: 523-532.

[7] Gunawardena H, Betteridge ZE, McHugh NJ. Myositis-specific autoantibodies: their clinical and pathogenic significance in disease expression. Rheumatology (Oxford) 2009; 48: 607-612.

[8] Tansley SL, Betteridge ZE, McHugh NJ. The diagnostic utility of autoantibodies in adult and juvenile myositis. Curr Opin Rheumatol. 2013; 25: 772-777.

[9] Betteridge ZE, McHugh NJ. Myositis-specific autoantibodies: an important tool to support diagnosis of myositis. J Intern Med. 2016; $280: 8-23$.

[10] Love LA, Weinberg CR, McConnaughey DR, et al. Ultraviolet radiation intensity predicts the relative distribution of dermatomyositis and anti-Mi-2 autoantibodies in women. Arthritis Rheum. 2009; 60: 2499-2504.

[11] Kashiwagi M, Morgan BA, Georgopoulos K. The chromatin remodeler Mi-2beta is required for establishment of the basal epidermis and normal differentiation of its progeny. Development 2007; 134: 1571-1582.

[12] Stone KB, Oddis CV, Fertig N, et al. Anti-Jo-1 antibody levels correlate with disease activity in idiopathic inflammatory myopathy. Arthritis Rheum. 2007; 56: 3125-3131.

[13] Love LA, Leff RL, Fraser DD, et al. A new approach to the classification of idiopathic inflammatory myopathy: myositis-specific autoantibodies define useful homogeneous patient groups. Medicine 1991; 70: 360-374

[14] Targoff IN, Johnson AE, Miller FW. Antibody to signal recognition particle in polymyositis. Arthritis Rheum. 1990; 33: 13611370 .
[15] Hengstman GJ, ter Laak HJ, Vree Egberts WT, et al. Anti-signal recognition particle autoantibodies: marker of a necrotising myopathy. Ann Rheum Dis. 2006; 65: 1635-1638.

[16] Miller T, Al-Lozi MT, Lopate G, et al. Myopathy with antibodies to the signal recognition particle: clinical and pathological features. J Neurol Neurosurg Psychiatry 2002; 73: 420-428.

[17] Suzuki S, Hayashi YK, Kuwana M, et al. Myopathy associated with antibodies to signal recognition particle: disease progression and neurological outcome. Arch Neurol. 2012; 69: 728732 .

[18] García-De La Torre I. Clinical usefulness of autoantibodies in idiopathic inflammatory myositis. Front Immunol. 2015; 6: 331.

[19] Reeves WH, Nigam SK, Blobel G. Human autoantibodies reactive with the signal-recognition particle. Proc Natl Acad Sci USA 1986; 83: 9507-9511.

[20] Schmidt J, Dalakas MC. Pathomechanisms of inflammatory myopathies: recent advances and implications for diagnosis and therapies. Expert Opin Med Diagn. 2010; 4: 241-250.

[21] Christopher-Stine L, Casciola-Rosen LA, Hong G, et al. A novel autoantibody recognizing $200-\mathrm{kd}$ and $100-\mathrm{kd}$ proteins is associated with an immune-mediated necrotizing myopathy. Arthritis Rheum. 2010; 62: 2757-2766.

[22] Benveniste O, Drouot L, Jouen F, et al. Correlation of anti-signal recognition particle autoantibody levels with creatine kinase activity in patients with necrotizing myopathy. Arthritis Rheum. 2011; 63: 1961-1971.

[23] Bodoki L, Vincze M, Hortobágyi T, et al. Anti-signal recognition particle autoantibody positive myopathy. [Szignálfelismero"részecske-ellenes autoantitest-pozitív myopathia.] Ideggyogy Sz. 2014; 67: 347-353. [Hungarian]

[24] Rider LG, Koziol D, Giannini EH, et al. Validation of manual muscle testing and a subset of eight muscles for adult and juvenile idiopathic inflammatory myopathies. Arthritis Care Res (Hoboken) 2010; 62: 465-472.

[25] Dankó K, Vincze M. New therapeutic approaches for polymyositis and dermatomyositis. [A polymyositis és dermatomyositis modern kezelési lehetőségei.] Orv Hetil. 2011; 152: 15521559 .

(Botos Balázs dr., Miskolc, Andor utca 20., 3532 e-mail: balazsbotos91@gmail.com

\section{"A malis vituperari laus est." (A gonoszok gyalázkodása dicséretnek számít.)}

